\title{
Influence of Cooperative Learning Model of Bamboo Dancing to Students Learning Outcomes in Social Sciences in Elementary School
}

\author{
Sri Rohartati \\ Universitas Langlangbuana \\ sriemultazam@gmail.com
}

\begin{abstract}
Astract: This research is entitled, The Influence of Cooperative Learning Models Type Bamboo Dancing Against Learning Outcomes of Students in Social Sciences Subjects in Primary Schools. This study aims to describe the implementation and influence of the cooperative model type bamboo dancing on improving student learning outcomes in social science subjects. The research method used was an experiment with the nature of quantitative research. The research design used is Quasi Experimental Design. The population of this study were students of the Public elementary School Mandalawangi district Cipatat West Bandung District. The research instrument uses observation sheets and test questions. The results of the test research data show that there is an increase in learning outcomes of students in social studies learning in elementary schools with the use of a cooperative type type bamboo dancing, can be seen from the results of the t-test on the sig (2-tailed) section showing differences in learning outcomes of students in post- the test obtained 0,000 this shows $0,000<0,05$, then $\mathrm{H}_{0}$ is rejected means that there is a significant difference in the learning outcomes of students between the experimental class and the control class there are differences after treatment. $\backslash$. Based on the proof of the hypothesis that reads "there is a significant influence on cooperative learning models of bamboo dancing type on the learning outcomes of students on social science subjects in elementary schools", the $\mathrm{H}_{1}$ hypothesis is accepted.
\end{abstract}

Keywords: Bamboo Dancing Method; Learning outcomes of students; Social Education Sciences

\section{Introduction}

\subsection{Background Problems}

Models that are generally implemented in teaching and learning activities are still centered on educators (teachers centered), knowledge gained by learners in a finished form through conventional methods. Results from observations in elementary school Mandalawangi Researchers have gained the description that, during this time the study used still emphasizes the concepts that exist in the book and underutilizes the environment as well as less leverage on resources Learning around the school. In addition, the learning methods applied by educators are not yet varied, still traditional and monotonous. In this traditional approach, learning does not give learners the opportunity to be active in the learning process, and also on this model, educators act as information centres, so that the learners tend to be passive and reluctant to ask or 
express opinions. As a result, lessons can be something that invites a variety of problems, namely learners are less active in learning, learners lack of cooperation and socialization among other learners, lack of tolerance, participants Students are less motivated in learning, and low student learning outcomes.

In learning cooperative model there are several methods such as methods of learning Bamboo Dancing (Bamboo Dance). Bamboo Dance is a modification of small circles and large circles. This Model has the advantage when used for teaching materials that require the exchange of student experience and knowledge. Therefore, it is hoped that using a cooperative learning model of Bamboo Dancing will improve students ' learning outcomes, because many students ' activities, such as brainstorm with other learners, present the Exchange results Thoughts, and pour the exchange of thoughts in the form of writing.

\subsection{Research Objectives}

The purpose of this study, namely: To obtain information about the influence of cooperative Model defense type Bamboo Dancing towards learning outcomes learners on the subject of social sciences in elementary school.

\section{Library Overview}

\subsection{Cooperative Learning Type Bamboo Dancing}

Sanjaya (2008:203) One of the methods offered cooperative learning is the Bamboo Dancing method. Bamboo Dancing is a modification of a small circle of large circles, developed by Spencer Kagan. The learning of Bamboo Dancing type is also often called bamboo dance, because the students lined and face each other with a similar strategy of two pieces of bamboo used in Filipino bamboo dance which is also popular in some areas in Indonesia. In the learning activities with the Bamboo Dancing method, learners face each other and share information. The course approach is commonly used with Bamboo Dancing type such as social science, religion, mathematics and language. These types of lessons are materials that require an exchange of experience, thoughts, and information between learners.

\subsubsection{Steps in the learning activities of Bamboo Dancing}

Huda (2013:148) Here are the steps in the learning activities of Bamboo Dancing: 1) determining the topic; 2) Divide the class into two large groups; 3 ) discussing the topics specified; 4) learners spin once clockwise; 5) The results of the discussion in front of the class; 6) Ask for comments or responses from other groups.

If viewed from the steps of type Bamboo Dancing is basically a discussion activity where learners discuss to solve the problem, which distinguishes that each learner has a chance to discuss with some learners More and more so it has more and different information. In this model the students are required to be more active and donate their opinions. 


\subsubsection{Advantages and disadvantages of Bamboo Dancing type learning}

According to Istarani (2011:83), this learning Model is suitable or well-used for materials that require the exchange of mind-and-information experience among learners. Therefore the excess of this method is:

(1) Learners can exchange experiences with their Fellowman in the learning process.

(2) Increase cooperation among learners

(3) Increase tolerance among fellow learners

Lack of cooperative learning Model type Bamboo Dancing, in addition to having advantages, models learn Bamboo Dancing also has some disadvantages, namely:

(1) The Learning Group is too fat to complicate the teaching process.

(2) Learners more play than learning.

(3) requires a fairly long period of time.

\subsection{Learning outcomes}

Hamalik (2010:135) "Learning outcomes are a statement of students ' ability to be expected to control some or all of the competencies in question. Where the indicator is a specific basic competence that can be used as a measure to assess the achievement of learning outcomes ". Based on the definition above, it can be concluded that the learning result is the result that the students gained after the learning process activities that are characterized by a better change. The results of the study were taken by teachers to be used as size or criteria in achieving an educational purpose. This can be achieved when the learners already understand learning with the change of behaviour to be better relative settled.

\subsubsection{Learning Outcomes Components}

This component of learning by Bloom's taxonomy classifies learning outcomes into three spheres of cognitive, affective and psychomotor.

Table 1. Components of learning Outcomes

\begin{tabular}{lll}
\hline No. & Realm & \multicolumn{1}{c}{ Aspects } \\
\hline 1. & Cognitive & 1. Knowledge \\
& & 2. Understanding \\
& & 3. Application of \\
& 4. Analysis \\
& & 5. Synthesis \\
& 6. Evaluation \\
\hline $2 . \quad$ Affective & 1. Pay attention to \\
& & 2. Responding \\
& 3. Internalize \\
& 4. The Pengoraganisasian \\
& 5. Characterization of \\
\hline 3. & 1. Perception \\
& & 2. Set \\
& & 3. Response \\
& 4. Mechanical response \\
& & 5. Complex response \\
\hline
\end{tabular}




\subsection{Social Sciences in elementary School}

The subjects of Social sciences were given starting elementary school level. According to Djodjo Suradisastra, (1993:6), suggests that the social sciences ' teaching is a broad study of people and their world. In this case, humans can be called as social creatures in the community. Learners as social beings cannot live individually but always live together with their neighbor in overcoming problems or obstacles in the learning process. Through the learning of social education, students are directed to be a democratic and responsible Indonesian citizen as well as citizens of the world who love peace.

\subsubsection{The character of your social Education elementary School}

Lili M Sadeli (2009:21) "Social education is a combined integrated or integrated social sciences. A unified understanding, that materials or materials of social education is taken from the social sciences combined and not fragmentary in the box of disciplines"

\subsubsection{Learning Objectives Social Education Sciences}

Purwarna (2009:13) "The purpose of learning social education is to educate and give the students basic skills to develop themselves according to their talents, interests and abilities and environment in the field of learning science Social education ".

\section{Research Methods}

In accordance with the problem in this research is about the influence of the model of cooperative-defence type Bamboo Dancing to the outcome of students learning on the subjects of social sciences in elementary school. Then the method used is the experimental method. Researchers use quantitative research properties according to Sugiyono, (2013:14) Quantitative research methods are research based on the philosophy of Postivism, pioneered by Auguste Comte, which is used to examine the population and Specific samples. The commonly selected sample collection technique is not random. The collection of data on this study uses research instruments and data analysis using statistics, which are characterized by numbers aiming to test the predetermined hypothesis.

The design of the experiments used for this research was Quasi experimental Design. The two forms of experimental quasi design are Time-Series Design and Nonequivalent Control Group Design. In this writing, researchers used the design of a Nonequivalent Control Group Design. (2013:116) This design is almost identical to the Pretest-Posttest Control Group Design, only on this design of the experimental group as well as the control group chosen is not random. Here's an overview of the design of Nonequivalent Control Group Design listed in Figure 1.

Figure 1. Nonequivelent Control Group

\begin{tabular}{|ccc|}
\hline $\mathrm{O}_{1}$ & $\mathrm{X}$ & $\mathrm{O}_{2}$ \\
\hdashline $\mathrm{O}_{3}$ & & $\mathrm{O}_{4}$ \\
\hline
\end{tabular}


Description: O1: Preliminary Tests (pretest) on the experiment group.

O2: Final Test (posttest) on the experiment group.

O3: initial test (pretest) on the control group.

O4: Final Test (posttest) on the control group.

$\mathrm{X}$ : Treatment

: The selected sample is not randomly

\subsection{Test Instrument Research}

\subsubsection{Data Validity Test}

The validity of the instruments is divided into two kinds of the validity and validity of the construct. The validity of the content in this study is to consult the experts, which are lecturers and teachers who are competent in the contents of the instruments that will be given to the learners. While the construct in this research is to conduct an instrument test and then measured results of initial ability.

Sugiyono (2014:128), valid or whether an instrument can be found by comparing the Product Moment Person correlation index with a significant level of 5\%. When the significance of the correlation result is greater than $0.05(5 \%)$ It is declared valid and otherwise if the significance of the correlation result is less than $0.05(5 \%)$ It is declared invalid. For validity testing, authors use the SPSS software 22 for Windows. In order to test the poll statement item, it must first be measured in validity (valid) by conducting a validity test. In the validity test, the problem is calculated using the following formula:

$$
r_{x y}=\frac{n \sum X Y-\sum X \sum Y}{\sqrt{\left(n \sum X^{2}-\left(\sum X\right)^{2}\right)}\left(n \sum Y^{2}-\left(\sum Y\right)^{2}\right)}
$$

Sumber: Arikunto (2014, hlm. 213)

Keterangan:

$\mathrm{r}_{\mathrm{xy}}$ : koefisien antara variabel $x$ dan variabel $y$

$\mathrm{X}$ : skor satu butir soal

$\mathrm{Y}:$ skor total

$\mathrm{N}$ : banyaknya subjek (siswa)

$\Sigma \mathrm{x}:$ jumlah skor pada item dari seluruh responden uji coba

$\Sigma y \quad$ : jumlah skor total seluruh item dari keseluruhan responden

Table 2. Validity Interachievements

\begin{tabular}{cc}
\hline Nilai $\mathbf{r}_{\mathbf{x y}}$ & Interpretasi \\
\hline $0,00<r_{x y} \leq 0,20$ & Validitasnya kecil \\
$0,20<r_{x y} \leq 0,40$ & Validitasnya rendah \\
$0,40<r_{x y} \leq 0,70$ & Validitasnya sedang \\
\hline $0,70<r_{x y} \leq 0,90$ & Validitasnya tinggi \\
$0,90<r_{x y} \leq 1,00$ & Validitasnya sangat tinggi \\
\hline
\end{tabular}




\subsubsection{Reliability Test}

Test the reliability of the instruments in this study using SPSS 22 for Windows. The internal reliability test is conducted by testing the instrument only once, and then the data obtained is analyzed by a terttentu technique. Reliability of the instrument can be done with a two-split technique from Spearman Brown (Split Half) as the following formula:

Description:

$$
\mathrm{ri}=\frac{2 \mathrm{rb}}{1+\mathrm{rb}}
$$

ri: Internal realiability of all instruments

rb: Correlation product moment between the first and second hemispheres

Table 3. Koefesien reachievement

\begin{tabular}{cc}
\hline Nilai & Keterangan \\
\hline $0.80<\mathrm{r}_{11} \leq 1.00$ & Sangat Tinggi \\
$0.60<\mathrm{r}_{11} \leq 0.80$ & Tinggi \\
$0.40<\mathrm{r}_{11} \leq 0.60$ & Sedang \\
$0.20<\mathrm{r}_{11} \leq 0.40$ & Rendah \\
$0.00<\mathrm{r}_{11} \leq 0.20$ & Sangat Rendah \\
\hline
\end{tabular}

Table 4. Test

Results

\begin{tabular}{ccc}
\hline Reliability value & Interpretation & Reliability Test \\
\hline 0,88 & Tinggi \\
\hline
\end{tabular}

\subsubsection{Power differentiator}

According to Zainal Arifin (2013:247) Distinguishing power is the measurement of the extent to which an item is able to distinguish learners who have been able to master competence based on certain criteria. The higher the differentiator power, the more capable grain problem distinguishes learners who have been able to master the competencies that have been given with the learners who are less or have not been able to master the competencies that have been given. To measure the distingutifying power in the researcher's item use the following formula:

$$
\mathrm{D}=\frac{B_{A}}{J_{A}}-\frac{B_{B}}{J_{B}}=P_{A}-P_{B}
$$

Sumber: Arikunto (2012, hlm.228)

Description:

A: Number of learners

JA: The number of group participants

JB: Number of group participants

BA: The number of group participants who answered the question correctly

BB: The number of lower group participants who answered the question correctly

PA: Proportion of Upper group participants who answered correctly

PB: Proportion of lower group participants who answered correctly 
The following is a table of differentiator power interachievements used in this study.

Table 5. Power Interachievement differentiator

\begin{tabular}{cc}
\hline Power Differentiator & Interpretation \\
\hline $\mathrm{PD} \geq 0,70$ & Excellent \\
$0,40 \leq \mathrm{PD} \geq 0,70$ & Good \\
$0,20 \leq \mathrm{PD} \geq 0,40$ & Enough \\
$\mathrm{PD} \leq 0,20$ & Ugly \\
\hline
\end{tabular}

\subsubsection{Test normality}

Testing the normality test in this study using SPSS 22 for Windows. As for the following formula:

$\left.\begin{array}{llllll}\hline \mathbf{X} & \mathbf{F} & \mathbf{Z} & \mathbf{f}(\mathbf{z}) & \mathbf{s}(\mathbf{z}) & {[\mathbf{f}(\mathbf{z})-\mathbf{s}(\mathbf{z})}\end{array}\right]$

Description:

$\mathrm{X}=$ poll on data

$\mathrm{Z}=$ transformation from number to notation on normal distribution

$\mathrm{F}(\mathrm{z})=$ Normal combative probality

$\mathrm{S}(\mathrm{z})=$ The proximal probality of the empirical

Conclusions gained are:

The determination of the significance, which is at a significance of $5 \%(0.05)$ and the hypothesis proposed as follows:

$\mathrm{H}_{0}$ : Normal Distribution samples

$\mathrm{H}_{1}$ : Undistribution of normal samples

Determination of normality, used rules:

If the $\mathrm{L}$ counts the $<\mathrm{L}$ table, then Ho is accepted. If $\mathrm{L}$ counts $>\mathrm{L}$ table, then Ho is rejected.

\subsubsection{Test homogeneity}

The homogeneity test aims to see the variances researched whether the two groups are equal or different by testing the homogeneity of the two variances is the variance of the initial test and the final test of both the experimental group and the control group. Test testing of homogeneity in this study using SPSS 22 for Windows. As for the formula Test homogenity as follows:

$$
\boldsymbol{F}_{\text {count }}=\frac{\mathrm{S}_{\mathrm{b}}^{2}}{\mathrm{~S}_{\mathrm{k}}^{2}}
$$

Description:

$$
\begin{aligned}
F_{\text {count }} & = \\
\mathrm{S}_{\mathrm{b}}^{2} & =
\end{aligned}
$$




\author{
$\mathrm{S}_{\mathrm{k}}^{2} \quad=\quad$ Value searched \\ Largest variant \\ Smallest variant
}

To determine the criteria for testing homogeneity use the provisions, as follows:

1. If Fcount $<$ ftable, then the data is homogenous

2. If Fcount $>$ Ftabel, then the data is not homogeneous

\title{
3.1.5. Test Difference Average
}

Data processing is done to test the hypotheses that have been formulated. The hypotheses to be tested are related and related to the problem. To find out if between the model variables of the cooperative learning type Bamboo Dancing to the increase in learners ' learning results have a meaningful relationship, testing is necessary for the hypothesis. Testing this hypothesis using test-T. Test-T formula as follows:

$$
t=\frac{\bar{X}_{1}-\bar{X}_{2}}{\sqrt{\frac{S_{1}^{2}}{n_{1}}+\frac{S_{2}^{2}}{n_{2}}-2 r\left(\frac{S_{1}}{\sqrt{n_{1}}}\right)\left(\frac{S_{2}}{\sqrt{n_{2}}}\right)}}
$$

Description:

$$
\begin{aligned}
& \mathrm{X}^{-}{ }_{-} 1=\text { Average Sample } 1 \\
& \mathrm{X}^{-}{ }_{-}=\text {Average Sample } 2 \\
& \mathrm{~S} \_1=\text { default Deviation Sample } 1 \\
& \mathrm{~S} \_2=\text { raw Deviation Sample } 2 \\
& \llbracket \mathrm{S} \rrbracket \_1^{\wedge} 2=\text { Variance Sample } 1 \\
& \mathrm{~S} \__{-}{ }^{\wedge} 2=\text { Variance Sample } 2 \\
& \mathrm{r}=\text { Correlation between } 2 \text { samples }
\end{aligned}
$$

The research hypothesis form is as follows:

$\mathrm{H}_{0}$ : There is no significant influence between the student learning outcomes of the experimental group who apply the cooperative learning model of Bamboo Dancing with the control class using conventional learning models.

$\mathrm{H}_{1}$ : There is a significant influence between the student learning outcomes of the experimental group who apply the cooperative learning model of Bamboo Dancing with the control class using conventional learning models.

T-test calculations can be used in testing a paired sample hypothesis. This test uses SPSS 22 for Windows.

\section{Results Of Research And Discussion}

\subsection{Research results}

This study was conducted in students of elementary School 112 Pamoyanan Bandung class VA and VB who are following the IPS lesson. The number of students of the VA class is 20 people as an experimental class that uses the cooperative learning model of 
Bamboo Dancing type and VB as much as 20 people as a control class that uses the conventional learning model. Data of research results obtained from observations and outcomes in the form of (Pretest and posttest) on the subject matter of the national event regarding the proclamation of independence. During the learning process that educators use by demonstrating a process or situation that is being studied, either directly or using props in the experimental class using cooperative learning type Bamboo Dancing. The goal is to make learning more enjoyable and understandable for learners so that there is a change in learning outcomes for learners.

\subsubsection{The application of the Bamboo Dancing learning Model}

Observation conducted by researchers to learners shortly before treatment and after treatment, it aims to see if there is a change in learners either before or after treatment, observations calculated by Using the Microsoft Excel software listed in the table 6 below:

Table 6. Student observation Results

\begin{tabular}{ccccc}
\hline No & Treatment & Observasi & $\begin{array}{c}\text { Persentase } \\
(\mathbf{\%})\end{array}$ & Description \\
\hline \multirow{2}{*}{1.} & \multirow{2}{*}{ Before } & affective & 60 & Less \\
\cline { 3 - 4 } & Psychomotor & 65 & \\
\hline \multirow{2}{*}{2.} & \multirow{2}{*}{ After } & Afektif & 80 & Good \\
\cline { 3 - 4 } & & Psikomotor & 85 & Good \\
\hline
\end{tabular}

\subsubsection{Test Data Analysis}

Pretests group experiments and pretests the control group. Similarly, a posttest group of experiments that got the treatment of bamboo dancing model and posttest the control group whose learning is using conventional methods.

The result of the pretests of learners ' learning outcomes in IPS is the ability of learners before being given treatment. Test phases are as follows.

(1) test normality

This normality test is done against data obtained from the results of the experimental class pretests and the control class is presented as follows:

Tabel 7. Pretest Normality test Results

Test of Normality

\begin{tabular}{crrrrrrr}
\hline \multirow{2}{*}{ Kelas } & \multicolumn{3}{c}{ Kolmogorov-Smirnov } & \multicolumn{3}{c}{ Shapiro-Wilk } \\
& statistic & df & sig & statistic & \multicolumn{1}{c}{ df } & sig \\
\hline Pretest Eksperimen &, 171 & 20 &, 129 &, 941 & 20 &, 255 \\
Kontrol &, 174 & 20 &, 115 &, 931 & 20 &, 162 \\
\hline
\end{tabular}

To know the normal presence of a data, set the criteria as follows:

A. The level of test significance is $5 \%(0.05)$

B. If the significance obtained $>5 \%(0.05)$ then the sample comes from a population that is a normal distribution 
C. If the significance gained $<5 \%(0.05)$ then the sample comes from a population that is not normally. Distributed in the test results that can be seen from the table above, obtained significance value in the experimental class of 0.255 , because $0.255>0.05$, then Data obtained by the experimental class derived from the normal distribution population at a significance level of 0.05 . While the value of significance in the control class is $0.162>0.05$, then the data obtained by the control class comes from a population that is a normal distribution of the significance of 0.05 .

(2) Test homogenity

The results of the calculations for homogeneity tests on experimental groups and more complete control groups can be seen in Table 8 as follows:

Table 8. Test results of Pretest homogenity

Test of Homogeneity of Variances

Pretest

\begin{tabular}{rrrrrrr}
\hline Levene statistic & df1 & df2 & \multicolumn{2}{c}{ Sig } \\
\hline, 000 & & 1 & & 38 & 989 \\
\hline
\end{tabular}

According to the table 8 explains the results of the tests conducted on the Pretests class value of the experiment and the control class in order to identify that the data is derived from a population that has the same or homogeneous variance. The criteria for setting homogeneity are as follows:

A. The level of test significance is $5 \%(0.05)$

B. If the significance obtained $>5 \%(0.05)$ then the variance of each sample is equal (homogeneous)

C. If the significance gained $<5 \%(0.05)$ then the variance of each sample is not the same (not homogeneous) in the table above used a test tool namely Levene Statistic.

In Levene test Statistic obtained significance of 0.989 , because $0.989>0.05$ then data Derived from a population that has the same variance (homogeneous).

(3) Test t

Test $\mathrm{T}$ aims to find out if there is or no difference between two pieces of data. This test is done to find out if there is an average difference from the Posttest value in the experiment class and the control class. Attached to table 4.8 as follows:

Tabel 9. Test $\mathrm{t}$

\begin{tabular}{ccccc}
\hline Kelas & N & Mean & Std.Deviation & \multicolumn{1}{c}{$\begin{array}{c}\text { Std.Error } \\
\text { Mean }\end{array}$} \\
\hline Pretest "Eksperimen" & 20 & $\mathbf{8 6 , 5 0}$ & $\mathbf{8 , 1 2 7}$ & $\mathbf{1 , 8 1 7}$ \\
"Kontrol" & $\mathbf{2 0}$ & $\mathbf{7 4 , 7 5}$ & $\mathbf{8 , 1 8 8}$ & $\mathbf{1 , 8 3 1}$ \\
\hline
\end{tabular}

Based on the table 9 above shows the average difference between the experiment class Posttest and the control class values. With the average rating of the expedition class was 86.50 and the control class was 74.75. To do the average difference test then 
used test $T$. T test is done when the variances of both tested samples have been identical. Since the previous stage has been identified that both data have the same variant (homogeneous), then conducted T-Test with hypotheses as follows:

$\mathrm{H}_{0}: \mu 1=\mu 2$, there is no difference in the outcome of Sosia learning; Between the experiment class and the control class.

$\mathrm{H}_{1}: \mu 1 \neq \mu 2$, there is a significant difference in social learning outcomes.

The decision-making for this test is when the probability of $>\alpha$ then $\mathrm{H}_{0}$ is accepted. But when the probability of $<\alpha$ then $\mathrm{H}_{0}$ is rejected.

Tabel 10. Independen Sample Test

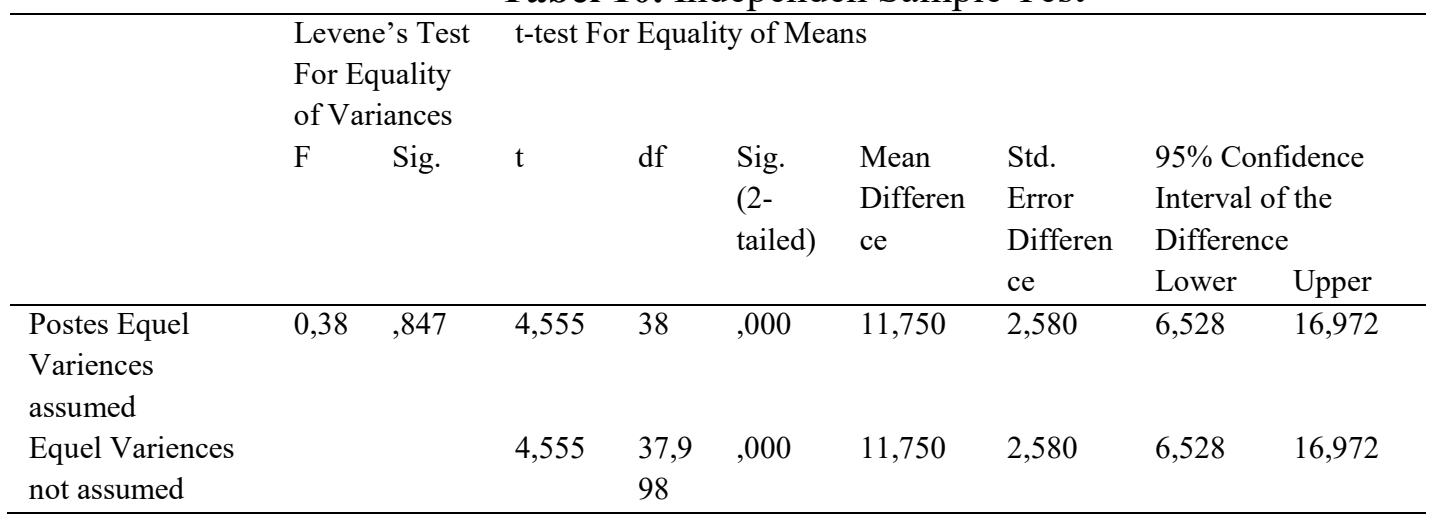

Based on the results of data on the table 4.9 shows t the count listed on the line Equal variance Assumed and column T-Test for Equality of Means precisely on the part of SIG. (2-tailed) worth 0.000 . Because $0.000<0.05$, the $\mathrm{H}_{0}$ rejected means that there is a better learning outcomes for learners in social science learning between experimental class learners and the control class learners.

\subsection{Discussion of research results}

Learning outcomes include three domains namely, cognitive, affective and psychomotor. To know the outcomes of the study of affective and psychomotor analysis through the results of observation data that has been attached in the previous page, the results of learning from the affective and psychomotor areas can be interpreted that after treatment in the class Experimentation there was a change in the affective and psychomotor of learners with an affective percentage of $80 \%$ while psychomotor $85 \%$ with the category of both domains could be expressed.

The hypothesis in this study is that there is a significant influence on the model of cooperative defense-type bamboo dancing towards students ' learning outcomes in the subjects of social sciences in elementary school. To test hypotheses then analysis of pretests data from experimental classes and control classes, this test was conducted using the normality test and homogeneity test first. The results of the analysis show that both of these classes are of normal distribution, then you do test-T to know the difference in the class of experiments and control classes.

The result of the research test data appears that there is an increase in learning outcomes of students in learning IPS in elementary school with the use of a cooperative model of bamboo dancing type, seen from the average increase of pretests and posttest 
of both classes, where The average increment of the experiment class is greater than the average increase in the control class. The average increase in the experimental class on pretests 54.25 after treatment with the bamboo dancing method is poured in posttest into 86.50 , so there is an excellent average hike. As for the average increase in the control class on Pretests 53.00 and on Posttes 74.75, the average class is not very good.

After knowing the average of the two classes, then to prove the difference between the experiment class and the control class was conducted testing using the-t test. The results of the test- $T$ in part sig (2-tailed) shows the difference in learning outcomes of learners on the pretests obtained 0.690 it shows $0.690>0.05$, then the H0 accepted means that in the experimental class and in the control class there is no difference of student learning outcomes. Shortly after being given treatment between classes of experiments using the bamboo dancing model with the control class using conventional models

Can be seen from the test-t results in part sig (2-tailed) shows the difference in the outcome of learners in Posttest obtained 0.000 this shows $0.000<0.05$, then $\mathrm{H} 0$ rejected means there is a significant difference in the outcome of the participants ' learning Between experimental classes and the control class there is a difference after treatment. This distinction states that experimental classes are superior and better results can be seen through the average student social learning results in experimental classes using bamboo dancing models.

Based on the explanation above, it shows that the application of the bamboo dancing learning model in the experimental class can be performed very well and the learning achievement. The results of this study also showed that the application of bamboo dancing models can further improve the learning outcomes of students, learners better understand the material taught, students can exchange experiences with their fellow friends in The learning process, can improve the sense of tolerance, students also work together in resolving problems in the learning Group by discussing it to facilitate the study process.

\section{Inferred}

Based on the results of research obtained and done processing and analysis of data, can be drawn conclusions as follows:

After testing there were influences on the use of models the study of bamboo dancing towards students ' learning outcomes on social subjects with the national event material about the proclamation of independence in elementary school. Based on the hypotheses that reads "There is a significant influence on the model of cooperative defense-type bamboo dancing towards student learning outcomes on the subjects of social sciences in elementary School" then the hypothesis Accepted.

\section{Bibliography}

[1] Arifin, Zenal., (2009). Evaluasi Pembelajaran. Bandung : PT Remaja Rosdakarya. 
[2] Arikunto, Suharsimi., (2015). Dasar-dasar Evaluasi Pendidikan. Jakarta : PT Bumi Aksara.

[3] Depdikbud. (2007). KTSP untuk Satuan Pendidikan Dasar SD/MI (Semester I dan II). Jakarta: BP Cipta Jaya.

[4] Djojo Suradisastra, dkk. (1993). Pendidikan IPS 3. Jakarta : Depdikbud Dirjen Dikti

[5] Hamalik, Oemar. (2009). Dasar-dasar Pengembangan Kurikulum. Bandung: PT Remaja Rosdakarya.

[6] Huda, Miftahul. (2013). Cooperative Learning Metode dan Model Penerapan. Yogyakarta: Pustaka Belajar..

[7] Istarani. (2011). Model Pembelajaran Inovatif. Medan: Media Persada.

[8] Lie, Anita.(2014). Cooperative Learning Mempraktikan Cooperaive Learning di Ruang-ruang Kelas. Jakarta: Grasindo.

[9] Linda, (2007). Pengaruh Model Pembelajaran Berbasis Portofolio Terhadap Hasil Belajar Siswa. Skripsi FPIPS UPI. Bandung: Tidak diterbitkan.

[10] Mukminan, (2004). Desain pembelajaran. Yogyakarta: Program Pascasarjana Universitas Negeri Yogyakarta.

[11] Mulyono Tjokrodikaryo. (1986). Perencanaan Pelaksanaan Pengajaran IPS. Jakarta: PT Bumi Aksara.

[12] Purwana, Agung Eko dkk.(2009) Pembelajaran IPS MI. Surabaya: Aprinta.

[13] Rusyan, Tabrani dan Daryani Yani. (1990). Penuntun Belajar yang Sukses. Jakarta: Nine Karya Jaya.

[14] Sadeli, Lili M. (2009). Dasar-Dasar Akuntansi. Jakarta: PT Bumi Akrasa.

[15] Sanjaya, Wina. (2008). Strategi Pembelajaran Berorientasi Standar Proses Pendidikan. Jakarta: Kencana Prenada Media Group.

[16] Sugiyono. (2015). Metode Penelitian Kuantitatif, Kualitatif, dan R\&D. Bandung: Alfabeta.

[17] Suprijono, Agus. (2010). Cooperative Learning: Teori dan Aplikasi PAIKEM. Yogyakarta: Pustaka Pelajar.

[18] Winataputra Udin S, dkk. (2007). Teori Belajar dan Pembelajaran. Jakarta: Universitas terbuka. 